\title{
Research Article \\ Effects of Blended-Cement Paste Chemical Composition Changes on Some Strength Gains of Blended-Mortars
}

\author{
Mehmet Serkan Kirgiz \\ Civil Engineering Department, Engineering Faculty, Hacettepe University, Beytepe, 06800 Ankara, Turkey \\ Correspondence should be addressed to Mehmet Serkan Kirgiz; nakres42@yahoo.com
}

Received 24 October 2013; Accepted 5 December 2013; Published 22 January 2014

Academic Editors: X. Jia and Y.-w. Yen

Copyright ( 2014 Mehmet Serkan Kirgiz. This is an open access article distributed under the Creative Commons Attribution License, which permits unrestricted use, distribution, and reproduction in any medium, provided the original work is properly cited.

Effects of chemical compositions changes of blended-cement pastes (BCPCCC) on some strength gains of blended cement mortars (BCMSG) were monitored in order to gain a better understanding for developments of hydration and strength of blended cements. Blended cements (BC) were prepared by blending of $5 \%$ gypsum and $6 \%, 20 \%, 21 \%$, and $35 \%$ marble powder (MP) or $6 \%, 20 \%, 21 \%$, and $35 \%$ brick powder (BP) for CEMI42.5N cement clinker and grinding these portions in ball mill at 30 (min). Pastes and mortars, containing the MP-BC and the BP-BC and the reference cement (RC) and tap water and standard mortar sand, were also mixed and they were cured within water until testing. Experiments included chemical compositions of pastes and compressive strengths (CS) and flexural strengths (FS) of mortars were determined at 7th-day, 28th-day, and 90th-day according to TS EN 196-2 and TS EN 196-1 present standards. Experimental results indicated that ups and downs of silica oxide $\left(\mathrm{SiO}_{2}\right)$, sodium oxide $\left(\mathrm{Na}_{2} \mathrm{O}\right)$, and alkali at MP-BCPCC and continuously rising movement of silica oxide $\left(\mathrm{SiO}_{2}\right)$ at BP-BCPCC positively influenced CS and FS of blended cement mortars (BCM) in comparison with reference mortars (RM) at whole cure days as MP up to $6 \%$ or $\mathrm{BP}$ up to $35 \%$ was blended for cement.

\section{Introduction}

Increasing of marble and brick manufacturing and lack of suitable landfills for wastes and ineffective purification systems for marble waste (MW) and brick waste (BW) have resulted in a move to raise both volume of these wastes and loss of the useful minerals. MW and BW occur, respectively, at 2,592,000 (tons) and 3,800,000 (tons) in Turkey every year as like whole world [1].

Activation of cement, such byproducts as fly ash (FA), silica fume (SF), MP, and BP, has been appealed by researchers for more than ten decades. Several researches have presented benefits of byproducts replaced by sand in mortar and concrete such properties as strength and workability [217]. Compatibility of byproducts for cement and mortar is assessed according to standard methods and technological studies (XRD, SEM, EDS, and TEM) and equations suggested by researchers to compute $\mathrm{C}_{3} \mathrm{~S}, \mathrm{C}_{2} \mathrm{~S}, \mathrm{C}_{3} \mathrm{~A}$, and $\mathrm{C}_{4} \mathrm{AF}$ compounds in cement [18-25]. Suggested standards, technological studies, and equations are inadequate to explain effects of blended-cement paste chemical composition changes on some strength gains of blended-mortars. Compounds linked strength gain at hydrated cement pastes are $\mathrm{C}_{3} \mathrm{~S}, \mathrm{C}_{2} \mathrm{~S}, \mathrm{C}_{3} \mathrm{~A}$, and $\mathrm{C}_{4} \mathrm{AF}$ are composed of $\mathrm{CaO}, \mathrm{SiO}_{2}$, $\mathrm{Al}_{2} \mathrm{O}_{3}$, and $\mathrm{Fe}_{2} \mathrm{O}_{3}$ known major oxides. Basically, these major oxides underlie the main reason for which cements show strength gain quickly (false strength) or strength gain slowly. However, $\mathrm{CaO}$ and $\mathrm{SiO}_{2}$ of OPC pastes at $28 \mathrm{~d}$ were, respectively, over $9 \%$ greater and over $6 \%$ less than that of OPC at $7 \mathrm{~d}$. Due to these changes of $\mathrm{CaO}$ and $\mathrm{SiO}_{2}$, OPC mortars at 28th-d showed over $25 \%$ greater quick strength gain in comparison with OPC mortars at 7th-d (Tables 3, 4, 5, and 6). This strength gain tendency of cement was considered to be able to change chemical compositions in which cement paste is hydrated by $\mathrm{C}_{3} \mathrm{~S}, \mathrm{C}_{2} \mathrm{~S}, \mathrm{C}_{3} \mathrm{~A}$ and $\mathrm{C}_{4} \mathrm{AF}$.

Therefore, this research was planned to monitor the effects of blended-cement paste chemical composition changes on some strength gains of blended mortars. This 
TABLE 1: Physical and pozzolanic properties of MP and BP and physical properties of CEMI42.5N cement [1].

\begin{tabular}{lccc}
\hline Physical Properties & MP & BP & CEMI42.5N \\
\hline $\begin{array}{l}\text { Fineness, (per cent) } \\
\quad 40 \mu \mathrm{m}\end{array}$ & 9.05 & 28.27 & 9.5 \\
$\quad 30 \mu \mathrm{m}$ & 3.58 & 5.85 & 0.3 \\
$\quad 1.34$ & 0.23 & 0.1 \\
$\quad 200 \mu \mathrm{m}$ & 2.53 & 2.12 & 3.11 \\
$\begin{array}{l}\text { Density }\left(\mathrm{gr} / \mathrm{cm}^{3}\right) \\
\text { Specific surface }\end{array}$ & 620.8 & 597.8 & 325 \\
$\begin{array}{l}\text { (Blaine method) }\left(\mathrm{m}^{2} / \mathrm{kg}\right) \\
\text { Water permeability }(\%)\end{array}$ & 16.35 & 40.10 & - \\
Pozzolanic properties & $\mathrm{MP}$ & $\mathrm{BP}$ & $\mathrm{CEMI} 42.5 \mathrm{~N}$ \\
$\begin{array}{l}\text { Compressive strength } \\
\text { (CS) (MPa) }\end{array}$ & 1.15 & 17.06 & - \\
$\begin{array}{l}\text { Flexural strength } \\
\text { (FS) }(\mathrm{MPa})\end{array}$ & 1.03 & 3.7 & - \\
\hline
\end{tabular}

paper does not address either the properties of concrete made with MP and BP or porosity effect for mortar strength gain or $\mathrm{CaCl}_{2}$ leaching effects on strength gains of mortars.

\section{Experimental Procedures}

2.1. Materials. Marble waste (MW), brick waste (BW), CEMI42.5N clinker, gypsum, and tap water were used for materials in this up-to-date experimental research. MW and BW were collected from plants which were found in Bilecik province and Kaman town in Turkey, respectively. CEMI42.5N clinker and gypsum were sent out SET Cement Factory in Ankara province. Marble waste or brick waste was granulated at thirty minutes in laboratory ball mill in order to make them a powder form (MP, BP) [1]. Chemical composition of MP composed of $53.79 \% \mathrm{CaO}, 0.388 \%$ $\mathrm{SiO}_{2}, \quad 0.11 \% \quad \mathrm{Al}_{2} \mathrm{O}_{3}, \quad 0.04 \% \quad \mathrm{Fe}_{2} \mathrm{O}_{3}, \quad 0.77 \% \mathrm{MgO}, 0.05 \%$ $\mathrm{SO}_{3}, 0.01 \% \mathrm{~K}_{2} \mathrm{O}, 0.34 \% \mathrm{Na}_{2} \mathrm{O}$, and $44.15 \%$ loss on ignition (LOI). Chemical composition of $\mathrm{BP}$ consisted of $12.88 \% \mathrm{CaO}$, $39.55 \% \mathrm{SiO}_{2}, 15.71 \% \mathrm{Al}_{2} \mathrm{O}_{3}, 14.05 \% \mathrm{Fe}_{2} \mathrm{O}_{3}, 3.29 \% \mathrm{MgO}, 0.48 \%$ $\mathrm{SO}_{3}, 1.98 \% \mathrm{~K}_{2} \mathrm{O}, 0 \% \mathrm{Na}_{2} \mathrm{O}$, and $11.30 \%$ LOI [1]. Chemical composition of CEMI42.5N included $65.09 \% \mathrm{CaO}, 21.01 \%$ $\mathrm{SiO}_{2}, 5.61 \% \mathrm{Al}_{2} \mathrm{O}_{3}, 3.52 \% \mathrm{Fe}_{2} \mathrm{O}_{3}, 1.55 \% \mathrm{MgO}, 0.87 \% \mathrm{SO}_{3}$, $0.86 \% \mathrm{~K}_{2} \mathrm{O}, 0.81 \% \mathrm{Na}_{2} \mathrm{O}$, and $0.30 \%$ LOI [26]. Because of MP's and BP's invaluable chemical compositions, assortment of MP is early strength gain activator and type of BP is unnatural pozzolana for cement, mortar, and concrete $[1,19,27]$. Physical and pozzolanic properties of MP, BP and physical properties of CEMI42.5N cement are shown in Table 1 [1].

MW or BW can also be partially added for CEMI42.5 cement clinker and gypsum in order to positively improve chemical compositions of cement pastes and strength gains of blended mortars according to physical and activation properties of MP and BP (Table 1) [1].

Mineralogical properties of MP measured by XRD are given in Figure 1. MP mainly contains middle pure levelcalcite $\left(\mathrm{CaCO}_{3}\right)$. There are found some other minor minerals,

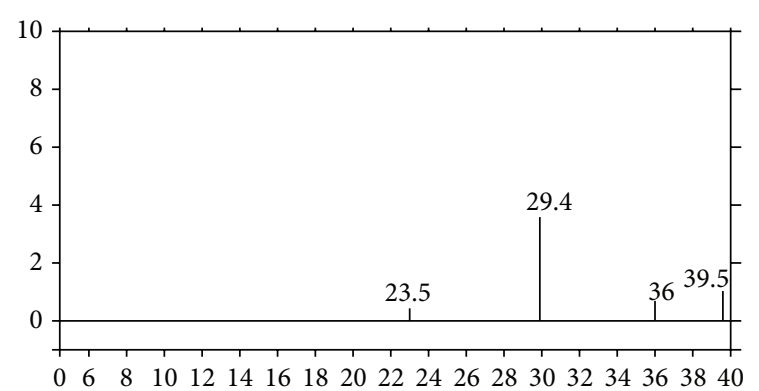

FIGURE 1: XRD diagram of MP [1].

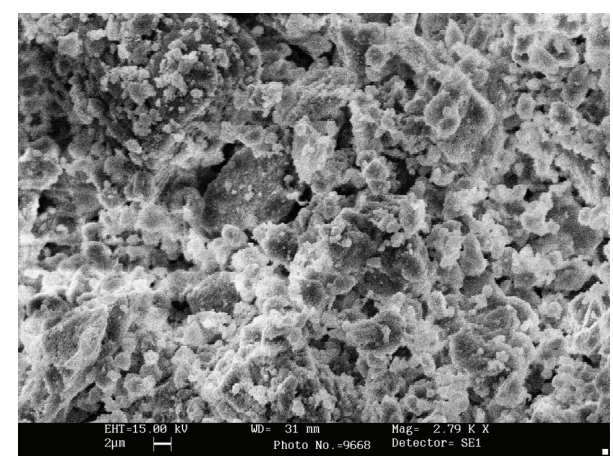

FIGURE 2: SEM image of MP microstructure [1].

for instance, quartz, dolomite, hematite, and magnetite in XRD pattern of MP (Figure 1) [1].

Figure 2 showed that most of the MP particles consisted of near-spherical and spheres were quite smooth. It is also apparent that MP is composed of various sized particles ranging from several to dozens of ultrafine micrometers. Additionally, microstructure of MP has slightly little spherical and amorphous hollow (Figure 2). There are mainly $\mathrm{Ca}, \mathrm{C}$, and $\mathrm{O}$ element peaks in EDS of MP similar to its chemical composition (Figure 3). As measured through absorbance spectra, results show that MP turned out big and little annular and sphere particle [1].

Figure 4 shows X-ray diffraction of BP. Characteristic mineralogical properties of $\mathrm{BP}$ consist of silica oxide $\left(\mathrm{SiO}_{2}\right)$, aluminum oxide $\left(\mathrm{Al}_{2} \mathrm{O}_{3}\right)$, magnesium orthosilicate $\left(2\left[\mathrm{Mg}_{0,96} \mathrm{Fe}_{0,04}\right] \mathrm{O} \cdot \mathrm{SiO}_{2}\right)$, and magnesium silicate $\left(\mathrm{Mg}_{2} \mathrm{SiC}_{4}\right)$ (Figure 4) [1].

SEM images of BP and EDS element counts of BP are shown in Figures 5 and 6, respectively. SEM observations of BP shown in Figure 5 indicated amorphous structure of BP. As measured through absorbance spectra, results show that BP turned out big and little annular and flat particle. Grains of BP exhibit irregular shapes with flat surfaces covered by small debris which are similar cement grains in paste and mortar. BP samples also contain immature needle-like products. It is apparent that populations of these products in the BP are significantly higher than that of the MP and these products are more compacted, as well (Figure 5) [1]. On the contrary to MP observations, BP includes plenty of rich silicate, aluminate, calcite, and hematite minerals which 


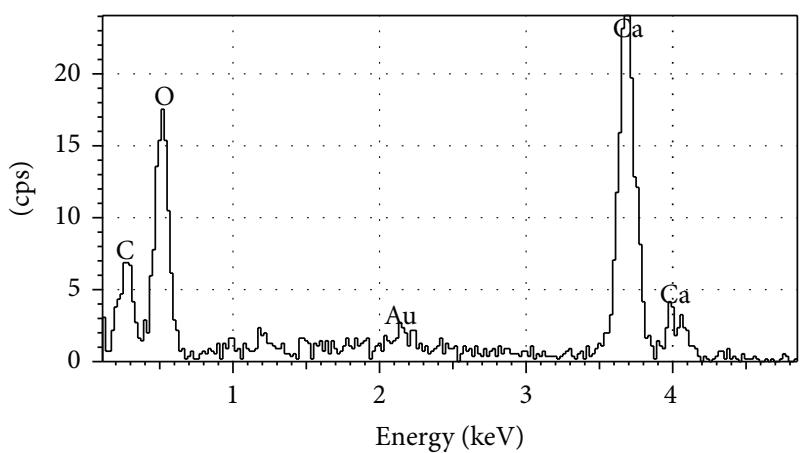

FIGURE 3: Element counts of MP [1].

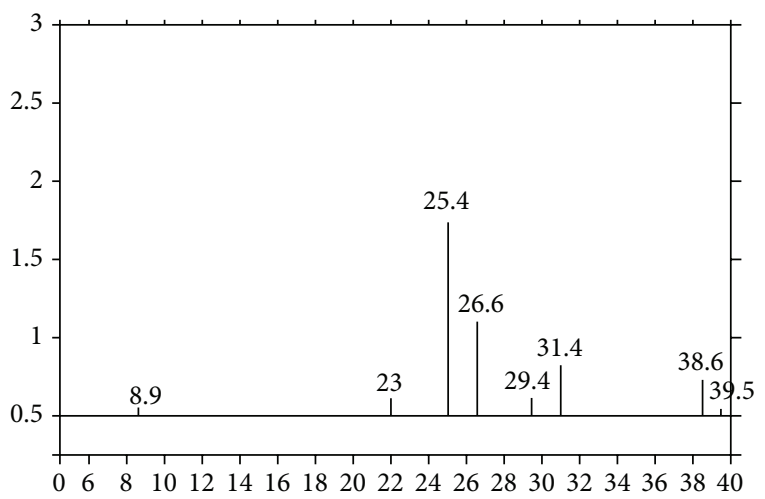

FIGURE 4: XRD diagram of BP [1].

reduce detrimental effects and provide to have much stable chemical compositions for cement. There are mainly $\mathrm{Ca}, \mathrm{Si}$, $\mathrm{Fe}, \mathrm{S}$, and $\mathrm{Al}$ element peaks in EDS of BP similar to its chemical composition (Figure 6) [1].

2.2. Sample Preparation. Difference of this research than others is that sample preparation consists of three stages. First stage is preparation of blended cements. Blended cements were prepared by blending of MW or BW for CEMI42.5N cement clinker at the percents of $6,20,21$, and 35 and adding gypsum up to $5 \%$, and these mixture proportions were grinded in ball mill together at $30 \mathrm{~min}$. Blending ratios of MW, BW, and gypsum for cement clinker were chosen according to TS EN 196-1 in order to be appropriate for this up-to-date standard. Codes of cement samples and mixture proportions and grinding time are given in Table 2 [1].

Second stage is preparation of cement pastes containing MP-blended cements or BP-blended cements or reference cement in order to measure chemical composition changes at 7th-d, 28th-d, and 90th-d. A medium planetary mixer was used for every paste mix using this following procedure: (1) add water and cements in bowl and mix them for $90 \mathrm{~s}$ at low speed; (2) stop mixer for $15 \mathrm{~s}$ to scrape bowl; mix for another $90 \mathrm{~s}$ at high speed; (3) cast pastes in cubic mold $50 \mathrm{~mm}$ for 4 min totally. Pastes were mixed with water: cement ratio of $1: 2[1,26,28]$.

Last stage deals with preparation of mortars containing MP-blended cements or BP-blended cements or reference

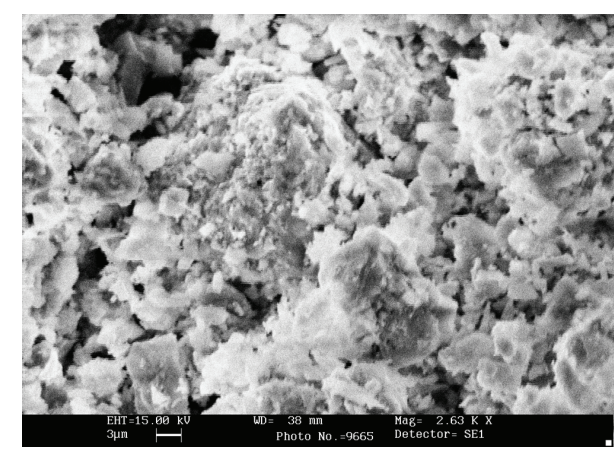

FIGURE 5: SEM image of BP microstructure [1].

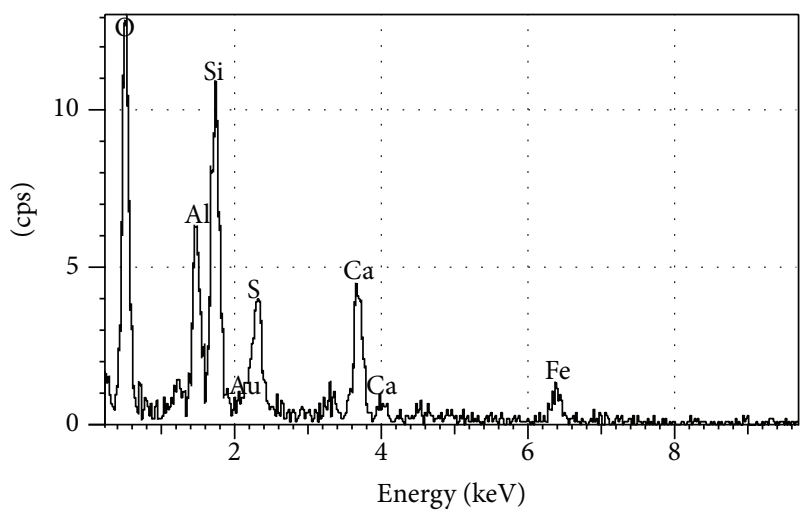

Figure 6: Element counts of BP [1].

cement for monitoring gains of CS and FS at 7th-d, 28th-d, and 90 th-d. In preparation of mortars, a medium planetary mixer was used for 4 min following procedure: (1) add water and cement in bowl; (2) mix them for $30 \mathrm{~s}$ at low speed; (3) add CEN standard sand at $30 \mathrm{~s}$; (4) mix them for $30 \mathrm{~s}$ at high speed; (5) stop the mixer for $15 \mathrm{~s}$ to scrape bowl; (6) mix for $60 \mathrm{~s}$ at high speed; (7) cast each mortar mixes in prism mould $40 \times 40 \times 160 \mathrm{~mm}$ as three layers; (8) collapse each layer 60 times $[1,28]$. Mortars were mixed with water: cement: sand ratio of $1: 2: 6$. Codes of blended cement mortars, reference cement mortars, and mixture proportions of mortars for one standard 3-gang mould are presented in Table 3 [1].

2.3. Methods. Experimental programs had three main goals: observe changes of some blended-cement paste morphology; analyze chemical composition changes of blended-cement pastes; monitor gains of compressive strength and flexural strength of mortars.

2.3.1. Morphology of Pastes. Some mortars continued strength gain at 7 th-d, 28th-d, and 90th-d although silica based chemical compositions of pastes went down. Therefore, CEMI42.5MP6P and CEMI42.5NBP20P pastes were observed in SEM equipped energy dispersive spectroscope (EDS) in order to better explain strength developments which were associated with $\mathrm{C}-\mathrm{S}-\mathrm{H}$ gel, $\mathrm{Ca}(\mathrm{OH})_{2}$, ettringite, $\mathrm{C}-\mathrm{A}-\mathrm{S}$, and unhydrated cement particles. All samples were coated with gold. SEM was set so the upper detector collected 
TABLE 2: Codes of cement samples and mixture proportions and grinding time [1].

\begin{tabular}{lccccc}
\hline Codes of cements & MW & BW & $\begin{array}{c}\text { Mixture proportions (\%) } \\
\text { Clinker CEMI42.5N }\end{array}$ & Gypsum & Grinding time (min) \\
\hline CLINKER CEMI42.5MP6 & 6 & 0 & 89 & 5 & 30 \\
CLINKER CEMI42.5MP20 & 20 & 0 & 75 & 5 & 30 \\
CLINKER CEMI42.5MP21 & 21 & 0 & 60 & 5 & 30 \\
CLINKER CEMI42.5MP35 & 35 & 0 & 89 & 5 & 30 \\
CLINKER CEMI42.5BP6 & 0 & 6 & 75 & 5 & 30 \\
CLINKER CEMI42.5BP20 & 0 & 20 & 60 & 5 & 30 \\
CLINKER CEMI42.5BP21 & 0 & 21 & 95 & 5 & 30 \\
CLINKER CEMI42.5BP35 & 0 & 35 & 0 & & 5 \\
CEMI42.5N (Reference) & 0 & & & 5 & 30 \\
\hline
\end{tabular}

TABLE 3: Codes of blended cement mortars, reference cement mortars, and mixture proportions for standard 3-gang mould Kirgiz, 2007 [1].

\begin{tabular}{|c|c|c|c|c|c|c|}
\hline \multirow{2}{*}{ Codes of cements } & \multicolumn{5}{|c|}{ Mixture proportions for standard 3-gang mould } & \multirow{2}{*}{ Water-binder ratic } \\
\hline & CEMI42.5N (g) & MP (g) & $\mathrm{BP}(\mathrm{g})$ & Sand $(\mathrm{g})$ & Water $(\mathrm{mL})$ & \\
\hline CEMI42.5MP6M & 423 & 27 & 0 & 1350 & 225 & 0.5 \\
\hline CEMI42.5MP20M & 360 & 90 & 0 & 1350 & 225 & 0.5 \\
\hline CEMI42.5MP21M & 355.5 & 94.5 & 0 & 1350 & 225 & 0.5 \\
\hline CEMI42.5MP35M & 292.5 & 157.5 & 0 & 1350 & 225 & 0.5 \\
\hline CEMI42.5BP6M & 423 & 0 & 27 & 1350 & 225 & 0.5 \\
\hline CEMI42.5BP20M & 360 & 0 & 90 & 1350 & 225 & 0.5 \\
\hline CEMI42.5BP21M & 355.5 & 0 & 94.5 & 1350 & 225 & 0.5 \\
\hline CEMI42.5BP35M & 292.5 & 0 & 157.5 & 1350 & 225 & 0.5 \\
\hline CEMI42.5NM (Reference) & 450 & 0 & 0 & 1350 & 225 & 0.5 \\
\hline
\end{tabular}

TABLE 4: 7th-day chemical compositions of marble and brick powder-blended and CEMI42.5N cement paste samples.

\begin{tabular}{lcccccccccc}
\hline \multirow{2}{*}{ Codes of pastes } & \multicolumn{9}{c}{ 7th-day chemical compositions (\%) } \\
& $\mathrm{CaO}$ & $\mathrm{SiO}_{2}$ & $\mathrm{Al}_{2} \mathrm{O}_{3}$ & $\mathrm{Fe}_{2} \mathrm{O}_{3}$ & $\mathrm{MgO}^{2}$ & $\mathrm{SO}_{3}$ & $\mathrm{~K}_{2} \mathrm{O}$ & $\mathrm{Na}_{2} \mathrm{O}$ & $\mathrm{LOI}^{2}$ & $\mathrm{Alkali}^{2}$ \\
\hline CEMI42.5MP6P & 49.35 & 16.22 & 4.34 & 3.35 & 6.38 & 2.40 & 0.24 & 0.33 & 17.16 & 0.49 \\
CEMI42.5MP20P & 54.65 & 14.34 & 3.26 & 3.36 & 1.84 & 2.35 & 0.22 & 0.20 & 19.03 & 0.35 \\
CEMI42.5MP21P & 55.59 & 14.30 & 3.06 & 2.34 & 2.08 & 2.65 & 0.30 & 0.18 & 19.10 & 0.38 \\
CEMI42.5MP35P & 54.24 & 11.60 & 2.98 & 2.34 & 1.65 & 3.52 & 0.33 & 0.25 & 22.95 & 0.47 \\
CEMI42.5BP6P & 52.36 & 17.26 & 4.10 & 4.13 & 1.07 & 3.24 & 0.25 & 0.24 & 17.23 & 0.41 \\
CEMI42.5BP20P & 46.44 & 19.98 & 6.29 & 5.24 & 1.45 & 3.84 & 0.63 & 0.29 & 15.62 & 0.71 \\
CEMI42.5BP21P & 44.36 & 19.36 & 6.48 & 5.17 & 2.86 & 4.80 & 0.45 & 0.25 & 15.59 & 0.55 \\
CEMI42.5BP35P & 42.67 & 21.78 & 6.94 & 6.29 & 2.08 & 5.70 & 0.55 & 0.30 & 13.67 & 0.66 \\
CEMI42.5NP (Reference) & 48.12 & 17.68 & 4.59 & 4.29 & 2.95 & 3.87 & 0.25 & 0.61 & 16.95 & 0.78 \\
\hline
\end{tabular}

TABLE 5: 28th-day chemical compositions of marble and brick powder-blended and CEMI42.5N cement paste samples.

\begin{tabular}{lcccccccccc}
\hline \multirow{2}{*}{ Codes of pastes } & \multicolumn{9}{c}{ 28th-day chemical compositions (\%) } \\
& $\mathrm{CaO}$ & $\mathrm{SiO}_{2}$ & $\mathrm{Al}_{2} \mathrm{O}_{3}$ & $\mathrm{Fe}_{2} \mathrm{O}_{3}$ & $\mathrm{MgO}^{2}$ & $\mathrm{SO}_{3}$ & $\mathrm{~K}_{2} \mathrm{O}$ & $\mathrm{Na}_{2} \mathrm{O}$ & $\mathrm{LOI}^{2}$ & $\mathrm{Alkali}^{2}$ \\
\hline CEMI42.5MP6P & 53.37 & 16.56 & 3.61 & 3.47 & 1.31 & 2.73 & 0.22 & 0.33 & 18.03 & 0.48 \\
CEMI42.5MP20P & 52.50 & 14.25 & 3.44 & 2.57 & 2.85 & 2.22 & 0.15 & 0.20 & 21.01 & 0.30 \\
CEMI42.5MP21P & 52.62 & 15.21 & 3.49 & 2.78 & 1.50 & 3.01 & 0.25 & 0.43 & 20.25 & 0.60 \\
CEMI42.5MP35P & 51.69 & 13.02 & 3.07 & 2.40 & 2.66 & 1.85 & 0.15 & 0.22 & 23.95 & 0.32 \\
CEMI42.5BP6P & 48.59 & 17.96 & 4.64 & 3.45 & 2.80 & 3.50 & 0.30 & 0.42 & 17.45 & 0.62 \\
CEMI42.5BP20P & 46.85 & 19.86 & 5.97 & 4.55 & 0.73 & 4.35 & 0.33 & 0.45 & 16.32 & 0.67 \\
CEMI42.5BP21P & 47.27 & 19.46 & 5.89 & 5.04 & 0.41 & 4.69 & 0.25 & 0.41 & 15.83 & 0.58 \\
CEMI42.5BP35P & 41.11 & 22.85 & 6.33 & 6.22 & 1.21 & 5.85 & 0.27 & 0.55 & 14.72 & 0.73 \\
CEMI42.5NP (Reference) & 52.84 & 16.72 & 3.97 & 3.21 & 1.30 & 2.35 & 0.26 & 0.30 & 18.67 & 0.47 \\
\hline
\end{tabular}


TABLE 6: 90th-day chemical compositions of marble and brick powder-blended and CEMI42.5N cement paste samples.

\begin{tabular}{lcccccccccc}
\hline \multirow{2}{*}{$\begin{array}{l}\text { Codes of pastes } \\
\end{array}$} & $\mathrm{CaO}$ & $\mathrm{SiO}_{2}$ & $\mathrm{Al}_{2} \mathrm{O}_{3}$ & $\mathrm{Fe}_{2} \mathrm{O}_{3}$ & $\mathrm{MgO}$ & $\mathrm{SO}_{3}$ & $\mathrm{~K}_{2} \mathrm{O}$ & $\mathrm{Na}_{2} \mathrm{O}$ & $\mathrm{LOI}^{2}$ & $\mathrm{Alkali}^{2}$ \\
\hline CEMI42.5MP6P & 51.69 & 14.92 & 4.05 & 3.07 & 2.23 & 2.26 & 0.03 & 0.11 & 21.34 \\
CEMI42.5MP20P & 52.56 & 12.84 & 3.67 & 2.68 & 1.98 & 2.37 & 0.06 & 0.11 & 23.18 & 0.13 \\
CEMI42.5MP21P & 51.69 & 12.76 & 3.55 & 2.63 & 1.45 & 3.29 & 0.03 & 0.09 & 24.31 & 0.11 \\
CEMI42.5MP35P & 52.29 & 10.84 & 2.69 & 2.87 & 1.75 & 3.26 & 0.05 & 0.11 & 26.01 & 0.14 \\
CEMI42.5BP6P & 49.87 & 16.78 & 5.14 & 3.64 & 1.98 & 3.50 & 0.08 & 0.09 & 18.49 & 0.14 \\
CEMI42.5BP20P & 45.63 & 19.36 & 6.24 & 4.98 & 2.47 & 1.99 & 0.24 & 0.14 & 18.36 & 0.30 \\
CEMI42.5BP21P & 44.96 & 22.52 & 6.13 & 4.93 & 1.74 & 2.98 & 0.22 & 0.09 & 16.23 & 0.24 \\
CEMI42.5BP35P & 40.99 & 25.82 & 7.08 & 5.80 & 1.79 & 3.74 & 0.40 & 0.18 & 13.98 & 0.44 \\
CEMI42.5NP (Reference) & 50.88 & 15.06 & 3.99 & 3.38 & 2.17 & 3.75 & 0.05 & 0.04 & 20.57 & 0.07 \\
\hline
\end{tabular}

the secondary electrons. SEM observations were performed on these samples using a LEO scanning electron microscope.

2.3.2. Chemical Compositions Experiment (with Wet Analysis). Blended-cement pastes and reference cement pastes were dried in laboratory and grinded at the end of curing days of the 7-day, 28-day, and 90-day ages. TS EN 196-2 standard was known wet chemical analysis was followed to analyze the chemical compositions of the pastes [26]. After $24 \mathrm{~h}$ casting in plastic mould in automatic controlled curing cabinet at 98\% relative humidity, these pastes were subjected to water curing in the same cure cabinet until testing at $21^{\circ} \mathrm{C}$ and $98 \%$ relative humidity. For each mix at each age, three samples were analyzed and the average value of 162 samples was taken to be the representative chemical properties.

2.3.3. Compressive Strength (CS) Experiment. CSs of mortars were determined cubic samples which were used portions of prisms broken in flexural strength experiment at $7 \mathrm{~d}, 28 \mathrm{~d}$, and $90 \mathrm{~d}$ in accordance to standard method [28]. For each mix at each age, twelve samples were tested with an ELE hydraulic testing machine and the average value of 324 samples was taken to be the representative strength.

2.3.4. Flexural Strength (FS) Experiment. Standard method was followed to measure flexural strength of prism mortar samples $40 \times 40 \times 160 \mathrm{~mm}$ with one-point loading at $7 \mathrm{~d}$, $28 \mathrm{~d}$, and $90 \mathrm{~d}$. After 1 day of casting, samples were demolded and cured in water in automatic controlled curing cabinet at $21^{\circ} \mathrm{C}$ and $98 \%$ relative humidity until testing. Curing water was refreshed fortnightly [28]. For each mix at each age, six samples were tested with an ELE hydraulic testing machine and the average value of 162 samples was taken to be the descriptive strength.

\section{Results and Discussions}

3.1. Influences of the BCP-SEM Image Changes to CS and FS of Blended Cement Mortars (BCM). Results of SEM observations and EDS graphs of hardened pastes of CEMI42.5MP6P and CEMI42.5NBP20P at 7th-d and 28th-d and 90th-d are presented in Figures 7 and 8. It was observed that in hydration of CEMI42.5MP6P at $7 \mathrm{~d}$, clinker grains were surrounded by radiating fibers of calcium silicate hydrate (C-S-H) resembling pattern of C-S-H of CEMI42.5 cement. Randomly oriented portlandite $(\mathrm{CH})$ crystals and prismatic ettringite crystals were widely dispersed through paste (Figure 7, upper left). However, in CEMI42.5MP6P at the ages of 7 days it was found that marble grains were covered with an amorphous (with respect to $\mathrm{C}-\mathrm{S}-\mathrm{H}$ ) layered $\mathrm{CH}$ hydration products. Matrix phase is mainly composed of short radicular outgrowths of C-S-Hs around clinker grains and needleshaped ettringite crystals (Figure 7, upper left). Microstructure of hydrated paste of CEMI42.5MP6P at the ages of 28 days was presented by amorphous gel filling spaces between hydrated particles. In pastes of CEMI42.5MP6P, layered accumulations of $\mathrm{CH}$ crystals of about $10 \mu \mathrm{m}$ in width are intermingled through paste (Figure 7 , middle left). There is a visible densification around marble grains due to partial hydration of marble grains, leading to formation of additional $\mathrm{CH}$. At the ages of 90 days marble grains were well located in matrix and were sunk in a layered $\mathrm{CH}$. Observation of paste based on CEMI42.5MP6P demonstrated that marble grains were turned out amorphous reaction prisms. In $\mathrm{CH}$ phase, matrix of CEMI42.5MP6P is found to be richer in calcium than that of reference cement paste. At 90th-day, microstructure of CEMI42.5MP6P was further densified with respect to reference cement paste (Figure 7, lower left).

However, compressive strength of CEMI42.5MP6M samples at whole cure periods is notably lower than that of brick powder-blended cement mortar (BP-BCM) and reference cement mortar (RCM). This can be explained by the difference at degree of hydration that occurs in each of two compounds such as $\mathrm{CH}$ and C-S-H. A lower degree of hydration occurs in cement paste with 6\% MP, where a number of hydration compounds are spotted during SEM imaging, shown in Figure 7. EDS analysis also supported that they were $\mathrm{CH}$, since they exhibited $\mathrm{Ca} / \mathrm{Si}$ ratios of between 1.76 and 2.8 at $7 \mathrm{~d}, 28 \mathrm{~d}$, and $90 \mathrm{~d}$. In comparison, hydrates exhibited none traces of carbon at whole periods. Therefore, this low compressive strength exhibited by CEMI42.5MP6M samples may be attributed to increasing of $\mathrm{Ca} / \mathrm{Si}$ ratio although $\mathrm{MP}$ is 

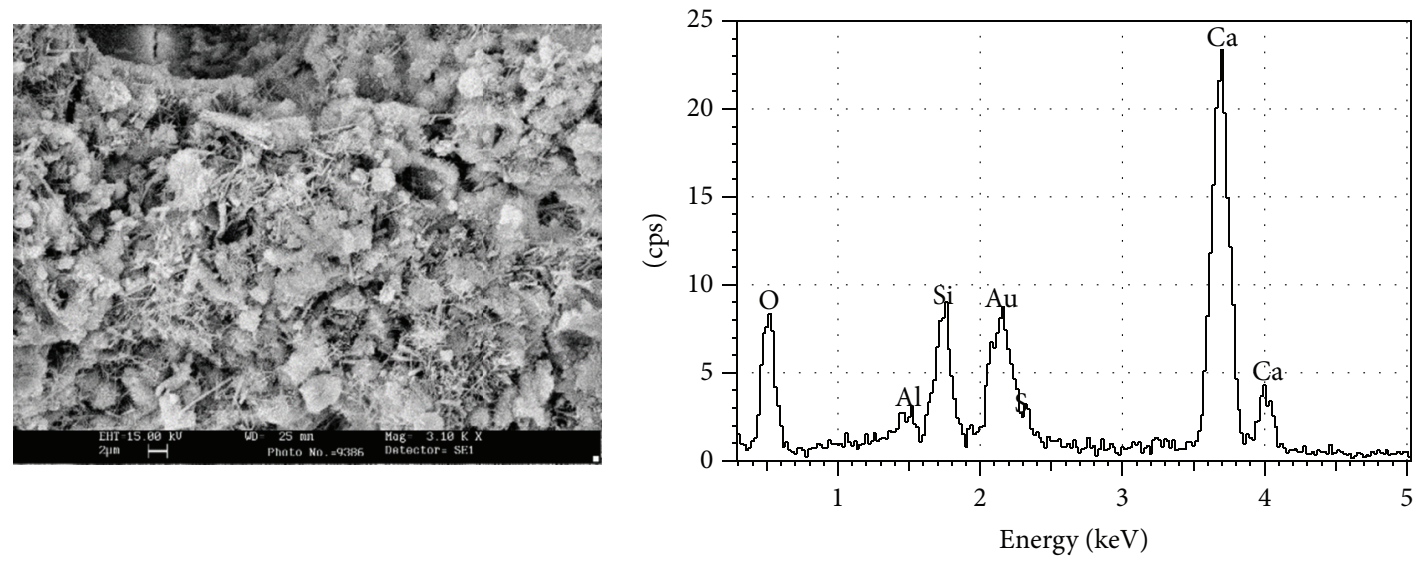

(a)
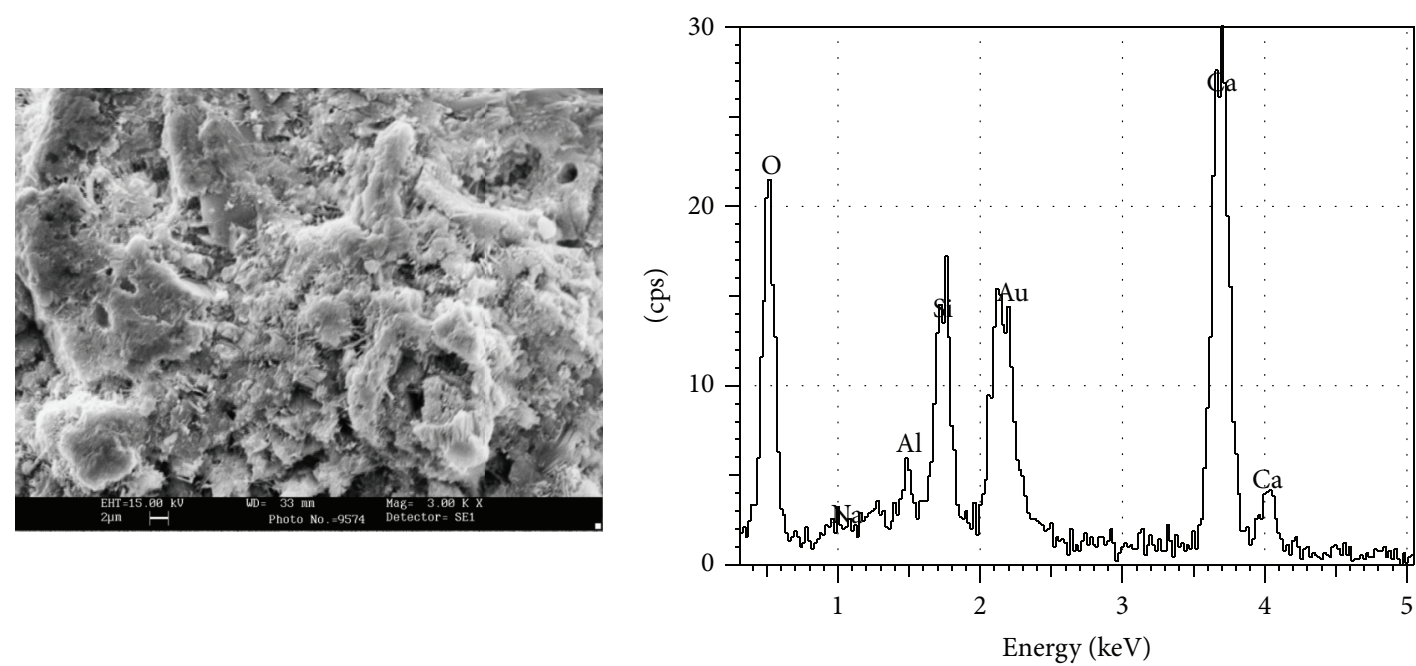

(b)
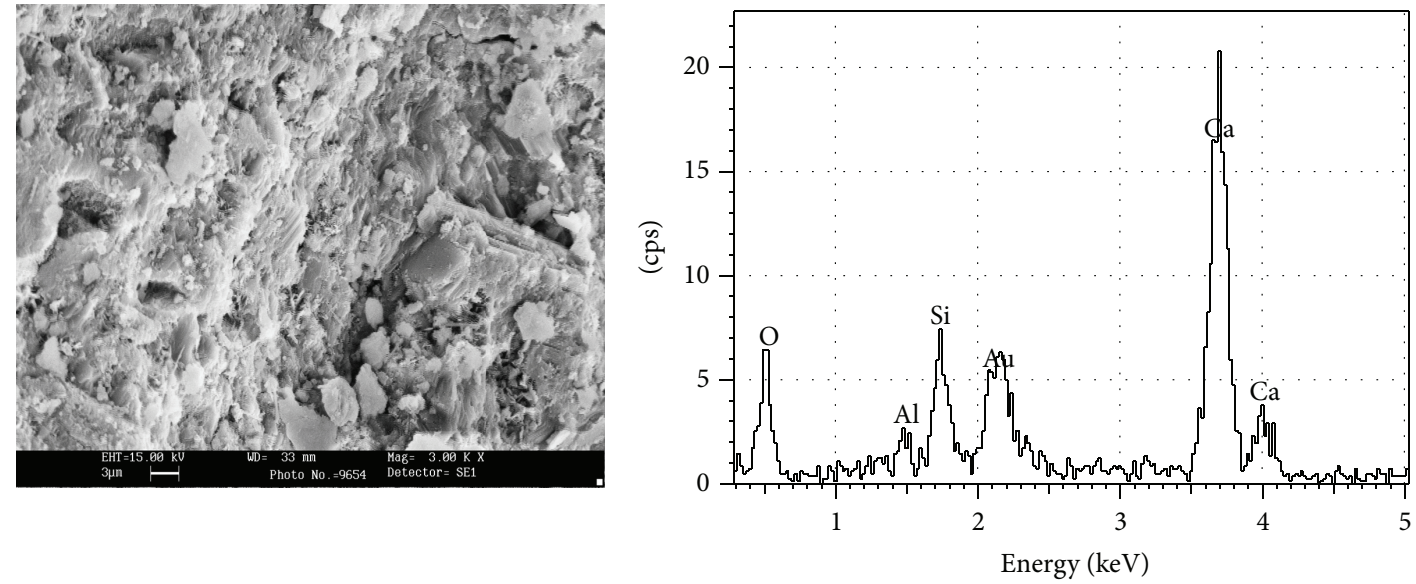

(c)

FIGURE 7: SEM images and EDS graphs observed for CEMI42.5MP6P at $7 \mathrm{~d}, 28 \mathrm{~d}$, and $90 \mathrm{~d}$.

aiding in densifying microstructure in cement systems by accelerating hydration (Figure 7).

For CEMI42.5BP20P at the ages of 7 days it was found that brick grains were covered with a numerous hydration products of $\mathrm{C}-\mathrm{S}-\mathrm{H}$ gel, layered $\mathrm{CH}$, prism ettringite, and little hollow. Matrix phase of CEMI42.5BP20P is mainly composed of short fibrous $\mathrm{C}-\mathrm{S}-\mathrm{H}$ forming around clinker grains and needle-shaped ettringite crystals, and randomly oriented portlandite $(\mathrm{CH})$ crystals are widely dispersed through paste (Figure 8, upper left). Microstructure of hydrated paste of 

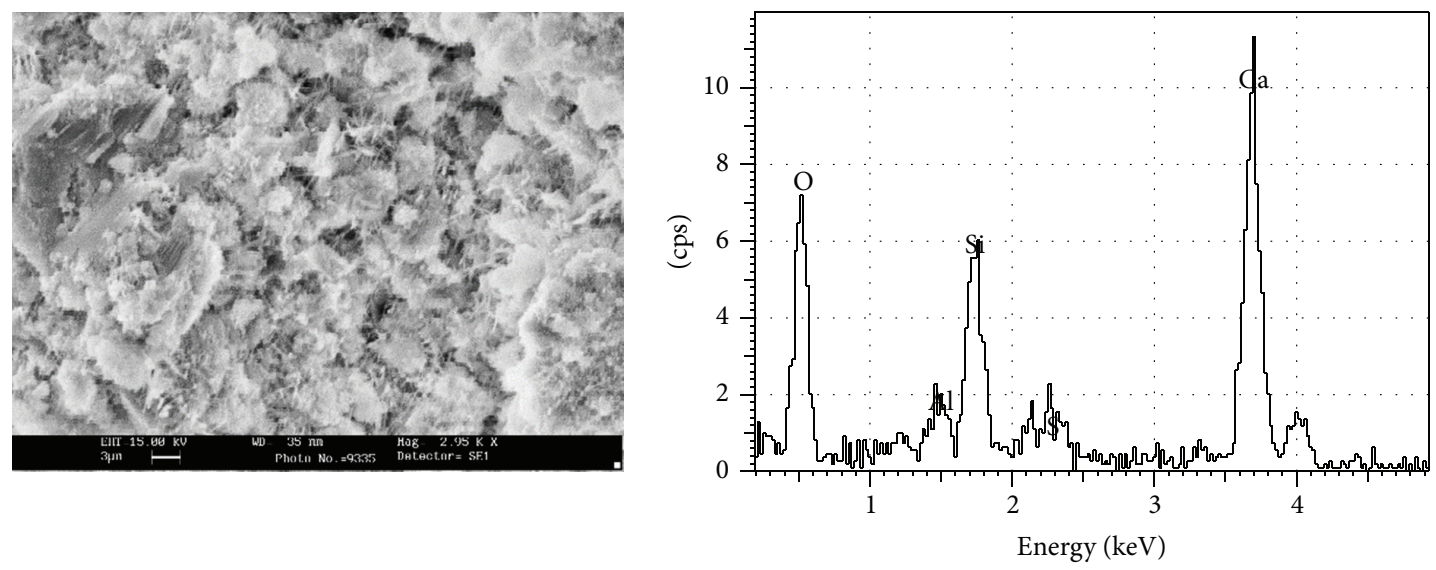

(a)
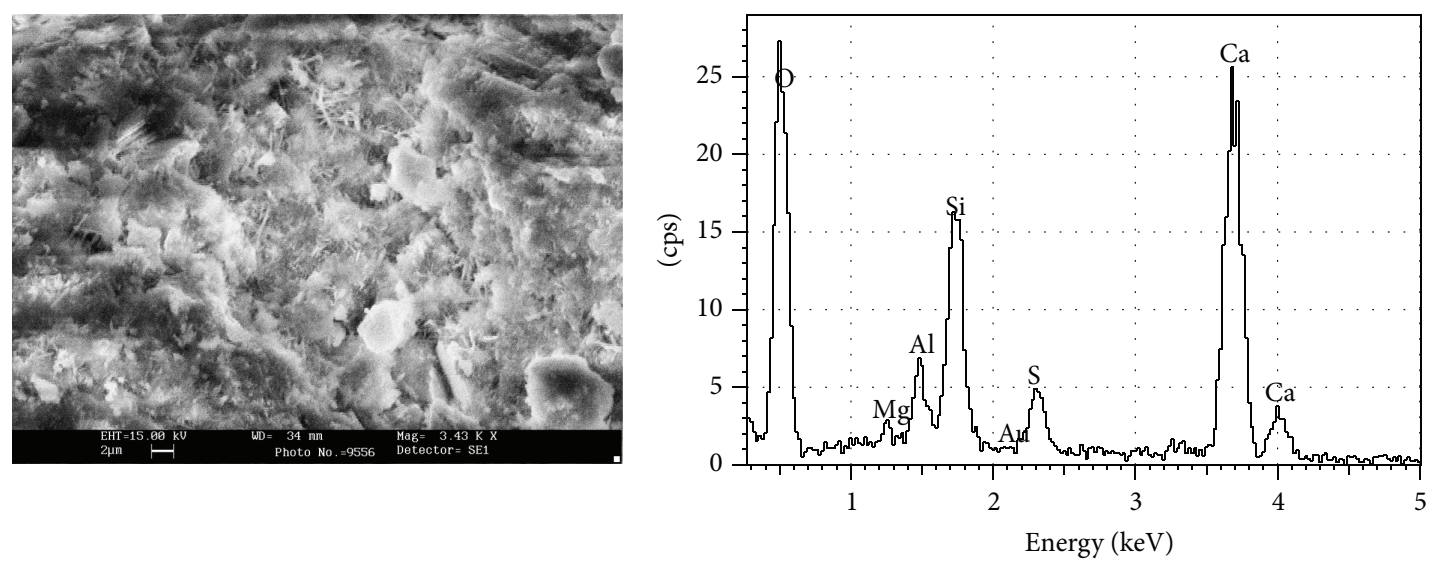

(b)
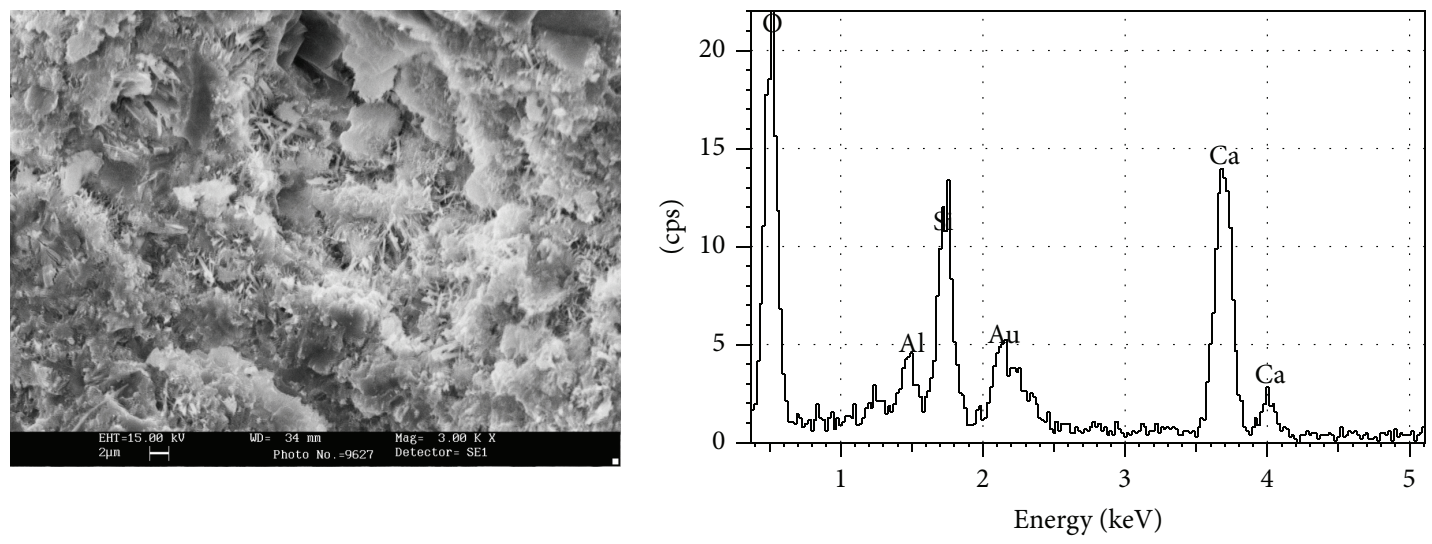

(c)

Figure 8: SEM images and EDS graphs observed for CEMI42.5BP20P at $7 \mathrm{~d}, 28 \mathrm{~d}$, and $90 \mathrm{~d}$.

CEMI42.5BP20P at the ages of 28 days was presented by amorphous gel filling hollow between hydrated particles; this gave certain stability to paste structure. In CEMI42.5BP20P pastes, layered accumulations of C-S-H crystals of about $3 \mu \mathrm{m}$ in width are intermingled through paste (Figure 8, middle left). There is a visible densification around brick grains due to partial hydration leading to formation of additional C-S$\mathrm{H}$. At the ages of 90 days, brick grains were well dispersed through matrix. And they penetrated in a layered $\mathrm{CH}$ in order to convert $\mathrm{CH}$ to fibrous $\mathrm{C}-\mathrm{S}-\mathrm{H}$ forming gel. Observation of paste based on CEMI42.5BP20P demonstrated that brick grains were turned out fibrous reaction prisms. In $\mathrm{C}-\mathrm{S}-\mathrm{H}$ phase, matrix of CEMI42.5BP20P was found to be richer in silicate with respect to reference cement at 90th-day (Figure 8, lower left).

However, compressive strengths of CEMI42.5BP20M samples at whole cure periods were the greatest in these mortars. This can be explained by difference at degree of 
TABLE 7: 7th-day and 28th-day and 90th-day CS and FS of marble and brick powder-blended and CEMI42.5N cement mortar samples [1].

\begin{tabular}{|c|c|c|c|c|c|c|}
\hline \multirow{2}{*}{ Codes of mortars } & \multicolumn{3}{|c|}{ Compressive strength (MPa) } & \multicolumn{3}{|c|}{ Flexure strength $(\mathrm{MPa})$} \\
\hline & 7th-day & 28th-day & 90th-day & 7th-day & 28th-day & 90th-day \\
\hline CEMI42.5MP6M & 31.76 & 40.72 & 42.61 & 5.40 & 6.26 & 6.37 \\
\hline CEMI42.5MP20M & 26.99 & 37.82 & 32.31 & 4.84 & 5.43 & 5.30 \\
\hline CEMI42.5MP21M & 24.61 & 32.52 & 30.26 & 4.66 & 5.00 & 5.13 \\
\hline CEMI42.5MP35M & 21.89 & 22.55 & 22.04 & 4.10 & 4.12 & 3.88 \\
\hline CEMI42.5BP6M & 37.35 & 42.74 & 42.76 & 5.26 & 6.37 & 6.59 \\
\hline CEMI42.5BP20M & 37.53 & 46.41 & 51.73 & 6.09 & 7.04 & 8.60 \\
\hline CEMI42.5BP21M & 31.18 & 43.92 & 44.08 & 4.62 & 6.43 & 7.59 \\
\hline CEMI42.5BP35M & 27.76 & 41.05 & 44.36 & 4.70 & 7.21 & 8.32 \\
\hline CEMI42.5NM (Reference) & 31.76 & 40.72 & 42.61 & 5.40 & 6.26 & 6.37 \\
\hline
\end{tabular}

hydration that occurs in each of one compound as C-S-H. A high degree of hydration occurs in cement paste with $20 \%$ $\mathrm{BP}$, where a number of hydration compounds are spotted during SEM imaging, shown in Figure 8. EDS analysis also supported that they were silicate, since they exhibited $\mathrm{Si} / \mathrm{Ca}$ ratios of about $0.53,0.63$, and 0.96 at $7 \mathrm{~d}, 28 \mathrm{~d}$, and $90 \mathrm{~d}$, respectively. In comparison, hydrates exhibited none traces of carbon at whole period. Therefore, the highest compressive strength exhibited by CEMI42.5BP20M samples may be attributed to increase of $\mathrm{Si} / \mathrm{Ca}$ ratio at 90th-day although BP was aiding in densifying microstructure in cement systems by accelerating strength gain slowly (Figure 8).

3.2. Influences of the CCC-BCP to CS and FS of Blended Cement Mortars. 7th-day, 28th-day, and 90th-day LOI and chemical properties of MP-blended cement pastes and BPblended cement pastes and CEMI42.5N cement pastes are presented in Tables 4, 5, and 6, respectively. Table 7 shows 7th-day, 28th-day, and 90th-day CS and FS of MP-blended mortars and BP-blended mortars and CEMI42.5N cement mortars [1].

According to the literature, results showed that mortars containing cement with high LOI were slower strength gains than that of mortars containing cement with low LOI. An increase in LOI of $1 \%$ can be anticipated to reduce mortar strength by nearly $4 \mathrm{MPa}[20-22,24,29-33]$. A parallel result was clearly observed in this research due to MP increased LOI in cement and cement pastes, too. As MP was increased up to $35 \%$ in cement paste by mass, averages of $\mathrm{CaO}, \mathrm{MgO}$, $\mathrm{K}_{2} \mathrm{O}$, and LOI of MP-blended cement pastes (MP-BCP) at $7 \mathrm{~d}$ were, respectively, over $11 \%, 1 \%, 9 \%$, and $15 \%$ higher with respect to reference paste (RP); averages of $\mathrm{SiO}_{2}, \mathrm{Al}_{2} \mathrm{O}_{3}$, $\mathrm{Fe}_{2} \mathrm{O}_{3}, \mathrm{SO}_{3}, \mathrm{Na}_{2} \mathrm{O}$, and alkali of MP-BCP at $7 \mathrm{~d}$ were over $20 \%, 26 \%, 34 \%, 29 \%, 61 \%$, and $46 \%$ less than that of RP. Changes of chemical compositions of MP-blended cement pastes (MP-BCPCC) at $7 \mathrm{~d}$ caused the decrease of both CS and FS of MP-blended mortars (MP-BM). CS and FS of MP$\mathrm{BM}$ were, respectively, over $23 \%, 7.5 \mathrm{MPa}$ and $12 \%, 0.6 \mathrm{MPa}$ less than that of reference mortars (RM) at $7 \mathrm{~d}$, except FS of CEMI42.5MP6M. It was surprisingly detected $0.03 \mathrm{MPa}$ greater FS of CEMI42.5MP6M in comparison with RM although CEMI42.5MP6P oxides changed such as other MPblended cement pastes at $7 \mathrm{~d}$ (Tables 3 and 6). Since MP was increased from $6 \%$ to $35 \%$ (over 5.5 times) in cement pastes, increasing of MP created 30\% CS and 24\% FS reduction associated with increasing of $9 \% \mathrm{CaO}, 46 \% \mathrm{SO}_{3}, 37 \% \mathrm{~K}_{2} \mathrm{O}$, and $33 \%$ LOI at MP-BM at $7 \mathrm{~d}$. In view of these changes of MP-BCPCC, CS and FS of MP-BM at $7 \mathrm{~d}$ were located in relatively wide ranges of 21.8-31.7 $\mathrm{MPa}$ and 4.1-5.4 MPa. These values are the lowest at MP-BMs. Increasing of MP in cement pastes caused a delay at strength of MP-BM at later ages, nevertheless, MP showed the most pronounced enhancing effect on strength gain at early ages: for $20 \% \mathrm{MP}$ mix at $28 \mathrm{~d}$, CS and FS could be improved by as much as $40 \%$ and $12 \%$ with respect to MP-BM at $7 \mathrm{~d}$, respectively, (Tables 4 and 7).

Similar strength reduction happened in MP-BM at $7 \mathrm{~d}$ was monitored at BP-BM. Since BP was augmented up to $35 \%$ in cement paste by mass, $\mathrm{BP}$ decreased $\mathrm{CaO}, \mathrm{MgO}, \mathrm{Na}_{2} \mathrm{O}$, LOI, and alkali over 3\%, 37\%, 56\%, 8\%, and 26\% lesser and also increased $\mathrm{SiO}_{2}, \mathrm{Al}_{2} \mathrm{O}_{3}, \mathrm{Fe}_{2} \mathrm{O}_{3}, \mathrm{SO}_{3}$, and $\mathrm{K}_{2} \mathrm{O}$ over $11 \%$, $30 \%, 21 \%, 14 \%$, and $88 \%$ higher in comparison with RP at $7 \mathrm{~d}$. Changes of chemical compositions of BP-blended cement paste (BP-BCPCC) resulted reducing both $\mathrm{CS}$ and FS of BP-blended mortars (BP-BM). CS and FS of BP-BM were, respectively, over $2 \%, 0.8 \mathrm{MPa}$ and $4 \%, 0.2 \mathrm{MPa}$ lower than that of RM at $7 \mathrm{~d}$, except CS of CEMI42.5BP6M and both CS and FS of CEMI42.5BP20M (Tables 3 and 6) [20-22, 24, 32, 33]. It was monitored that CEMI42.5BP20M had the greatest $\mathrm{CS}$ and FS in these mortars at $7 \mathrm{~d}$. Result infers that BP has got over $9 \%$ greater acceleration effect on strength gain with respect to RM at $7 \mathrm{~d}$. Nevertheless, this effect is not as high as blended mortars containing $20 \% \mathrm{MP}$ at $28 \mathrm{~d}$. As BP was increased from $6 \%$ to $35 \%$ (over 5.5 times) in cement pastes, the increasing of BP originated $25 \% \mathrm{CS}$ and $10 \% \mathrm{FS}$ reduction accompanying with increasing of $69 \% \mathrm{Al}_{2} \mathrm{O}_{3}, 52 \% \mathrm{Fe}_{2} \mathrm{O}_{3}$, $94 \% \mathrm{MgO}, 75 \% \mathrm{SO}_{3}, 220 \% \mathrm{~K}_{2} \mathrm{O}$, and $25 \% \mathrm{Na}_{2} \mathrm{O}$ at $\mathrm{BP}-\mathrm{BM}$ at $7 \mathrm{~d}$. In view of these changes of BP-BCPCC, CS and FS of $\mathrm{BP}-\mathrm{BM}$ at $7 \mathrm{~d}$ were located in relatively wide ranges of 27.737.5 MPa and 4.6-6 MPa. These values are the lowest in BPBM. However, BP showed the least pronounced enhancing effect on strength gain at early ages: for $20 \%$ BP mix at $28 \mathrm{~d}$, CS and FS were, respectively, improved by as much as $23 \%$ and $15 \%$ in comparison with $7 \mathrm{~d}$ (Tables 4 and 7 ).

It was shown in the literature that an increase in alkali of pastes reduced strength gain by nearly $1.5 \mathrm{MPa}$ at $28 \mathrm{~d}$ [20-22, 24, 29-33]. Strength reduction was not monitored in 
these research results as alkali did not escalate in MP-BCP at $28 \mathrm{~d}$. As MP was escalated up to $35 \%$ in cement paste by mass, averages of $\mathrm{MgO}, \mathrm{SO}_{3}$, and LOI of MP-BCP at $28 \mathrm{~d}$ were, respectively, over $60 \%, 4 \%$, and $11 \%$ greater than that of RP; averages of $\mathrm{CaO}, \mathrm{SiO}_{2}, \mathrm{Al}_{2} \mathrm{O}_{3}, \mathrm{Fe}_{2} \mathrm{O}_{3}, \mathrm{~K} 2 \mathrm{O}$, and $\mathrm{Na}_{2} \mathrm{O}$ and alkali of MP-BCP at $28 \mathrm{~d}$ were, respectively, over $0.5 \%$, $12 \%, 14 \%, 13 \%, 30 \%, 2 \%$, and $10 \%$ less than that of RP. Changes of MP-BCPCC at $28 \mathrm{~d}$ reasoned the reduction of both CS and FS of MP-BM. CS and FS of MP-BM were approximately over $24 \%, 9.5 \mathrm{MPa}$ and $17 \%, 1.05 \mathrm{MPa}$ less than that of RM at $28 \mathrm{~d}$, except CEMI42.5MP6M (Tables 5 and 7). It was detected that MP-BCPCCC caused over $26 \%$ and $9 \%$ greater CS and FS at $28 \mathrm{~d}$ than that of MP-BMs at $7 \mathrm{~d}$. These results infer that strength gain of MP-BM deals with alkali reduction of MP-BCPCC at $28 \mathrm{~d}$. Since MP was increased from $6 \%$ to $35 \%$ (over 5.5 times) in cement, this increasing brought about decreasing of $44 \%$ CS and $34 \%$ FS associated with increasing of $200 \% \mathrm{MgO}$ and $32 \% \mathrm{LOI}$ at MP-BMs at $28 \mathrm{~d}$. In view of these changes of MP-BCPCC, CS and FS of MP-BM at $28 \mathrm{~d}$ were located in relatively wide ranges of 22.5-40.7 MPa and 4.1-6.2 MPa. These values are higher than those of CS and FS at $7 \mathrm{~d}$ (Tables 5 and 7 ).

Strength reduction accompanying with increasing of alkali for BP-BCP was not observed at BP-BMs at $28 \mathrm{~d}$ [20$22,24,32]$. Strengths augmented nearly $0.5 \mathrm{MPa}$ at BP-BMs although alkali increased over $37 \%$ greater with respect to RP. Similar increase at $\mathrm{SiO}_{2}, \mathrm{Al}_{2} \mathrm{O}_{3}, \mathrm{Fe}_{2} \mathrm{O}_{3}, \mathrm{SO}_{3}, \mathrm{~K}_{2} \mathrm{O}$, and $\mathrm{Na}_{2} \mathrm{O}$ associated with increasing of $\mathrm{BP}$ up to $35 \%$ was, respectively, over $19 \%, 43 \%, 49 \%, 95 \%, 11 \%$, and $53 \%$ greater than that of RP. Decreasing at $\mathrm{CaO}, \mathrm{MgO}$, and LOI in BP-BCP was, respectively, over $13 \%, 1 \%$, and $14 \%$ less with respect to $\mathrm{RP}$ at $28 \mathrm{~d}$. Changes of BP-BCPCC caused growth of both CS and FS of BP-BM. CS and FS of BP-BM were over $1 \%, 0.4 \mathrm{MPa}$ and $8 \%, 0.5 \mathrm{MPa}$ greater in comparison with RM at $28 \mathrm{~d}$ (Tables 5 and 7). It was monitored that BP-BCPCCC caused over $30 \%$ greater CS and FS at BP-BMs at $28 \mathrm{~d}$ than that of BP$\mathrm{BMs}$ at $7 \mathrm{~d}$. It is clear that strength gain of BP-BM deals with reduction of $\mathrm{CaO}, \mathrm{MgO}$, and LOI of BP-BCPCC. Since BP was increased from $6 \%$ to $35 \%$ (over 5.5 times) in cement pastes; this increasing created 3\% CS reduction and 13\% FS gain associated with increasing of $27 \% \mathrm{SiO}_{2}, 36 \% \mathrm{Al}_{2} \mathrm{O}_{3}, 80 \%$ $\mathrm{Fe}_{2} \mathrm{O}_{3}, 67 \% \mathrm{SO}_{3}$, and $30 \% \mathrm{Na}_{2} \mathrm{O}$ at BP-BMs at $28 \mathrm{~d}$. In view of these changes of BP-BCPCC, CS and FS of BP-BM at $28 \mathrm{~d}$ were located in relatively wide ranges of $41-46.4 \mathrm{MPa}$ and 6.3-7.5 MPa. These values are lower in comparison with CS and FS of BP-BMs at $90 \mathrm{~d}$ (Tables 5 and 7).

Since MP was escalated up to $35 \%$ in cement paste by mass, averages of $\mathrm{CaO}, \mathrm{Na}_{2} \mathrm{O}$, LOI, and alkali of MP-BCP were, respectively, over $2 \%, 262 \%, 15 \%$, and $89 \%$ greater than that of RP at $90 \mathrm{~d}$; averages of $\mathrm{SiO}_{2}, \mathrm{Al}_{2} \mathrm{O}_{3}, \mathrm{Fe}_{2} \mathrm{O}_{3}, \mathrm{MgO}, \mathrm{SO}_{3}$, and $\mathrm{K}_{2} \mathrm{O}$ of MP-BCP were, respectively, over $15 \%, 13 \%, 17 \%$, $15 \%, 26 \%$, and $10 \%$ less than that of RP at $90 \mathrm{~d}[29-31,33]$. Changes of MP-BCPCC at $90 \mathrm{~d}$ originated reducing both CS and FS of MP-BM. CS and FS of MP-BM were over 27\%, $12 \mathrm{MPa}$ and $4 \%, 0.2 \mathrm{MPa}$ less than that of RM at $90 \mathrm{~d}$ (Tables 6 and 7). Since MP was increased from 6\% to $35 \%$ in cement pastes, this increasing reasoned reduction of $48 \%$ CS and $39 \%$ FS associated with increasing of $1 \% \mathrm{CaO}, 44 \% \mathrm{SO}_{3}, 7 \%$ alkali, and $22 \% \mathrm{LOI}$ at MP-BM at $90 \mathrm{~d}$. In view of these changes of MP-BCPCC, CS and FS of MP-BM at $90 \mathrm{~d}$ were located in relatively wide ranges of $22-42.6 \mathrm{MPa}$ and $3.8-6.5 \mathrm{MPa}$. These values are the highest in MP-BMs. However, enhancing effect of MP on strength gain gradually decreased over time and after 3 months CS of CEMI42.5MP35 mortar was lesser than that of both CEMI42.5MP6 and RM at $7 \mathrm{~d}$. This implies that MP blending more than $6 \%$ has not got positive effect on strength gain of cement mortars at later ages according to these findings of MP-BCPCCC and of MP-BM strength gain in this research (Tables 6 and 7).

On the contrary to last results regarding MP-BCPCCC, as $\mathrm{BP}$ was increased up to $35 \%$ in cement paste by mass, averages of $\mathrm{SiO}_{2}, \mathrm{Al}_{2} \mathrm{O}_{3}, \mathrm{Fe}_{2} \mathrm{O}_{3}, \mathrm{~K}_{2} \mathrm{O}, \mathrm{Na}_{2} \mathrm{O}$, and alkali of $\mathrm{BP}-$ BCP were, respectively, over $40 \%, 53 \%, 42 \%, 470 \%, 313 \%$, and $400 \%$ greater in comparison with $\mathrm{RP}$ at $90 \mathrm{~d}$; averages of $\mathrm{CaO}$, $\mathrm{MgO}, \mathrm{SO}_{3}$, and LOI of BP-BCP were, respectively, over $11 \%$, $9 \%, 19 \%$, and $18 \%$ less than that of RP at $90 \mathrm{~d}$. Changes of BP-BCPCCC at $90 \mathrm{~d}$ caused ascent of both CS and FS of BPBM. CS and FS of BP-BM were over $4 \%, 1.5 \mathrm{MPa}$ and $44 \%$, 2.33 MPa greater than that of RM at $90 \mathrm{~d}$. As BP was increased from $6 \%$ to $35 \%$ in cement, this increasing caused increasing of $20 \% \mathrm{CS}$ and $26 \% \mathrm{FS}$ associated with increasing of $53 \% \mathrm{SiO}_{2}$, $37 \% \mathrm{Al}_{2} \mathrm{O}_{3}, 60 \% \mathrm{Fe}_{2} \mathrm{O}_{3}$, and $6 \% \mathrm{SO}_{3}$ at $\mathrm{BP}-\mathrm{BM}$ at 90 d. In view of these changes of BP-BCPCC, CS and FS of BP-BM at $90 \mathrm{~d}$ were located in a relatively broad ranges of $42.7-51.7 \mathrm{MPa}$ and 6.5-8.3 MPa. These values are the greatest in CS and FS values in BP-BMs. Moreover, enhancing effect of $\mathrm{BP}$ on strength gain gradually increased over time and after 3 months; CS and FS of CEMI42.5BP35 mortars were greater than that of both CEMI42.5BP6 and RM at $7 \mathrm{~d}$. This infers that $\mathrm{BP}$ has positive effect on strength gain of cement mortars at later ages (Tables 6 and 7).

If changes of 90th-day MP-BCPCC are considered as final results, it could be generalized that effects of MP-BCPCCC on strength gain deal with fluctuation of $\mathrm{SiO}_{2}, \mathrm{Na}_{2} \mathrm{O}$ and alkali content. Similar ups and downs of $\mathrm{SiO}_{2}, \mathrm{Na}_{2} \mathrm{O}$ and alkali at MP-BCP are observed CS and FS gain at MP-BM as a bumpy characteristic. Both averages of 7th-day compositions and averages of 7 th-day strengths were lower in comparison with 28th-day and were higher with respect to 90th-day as shown in the following parentheses $\left(7 \mathrm{~d}: 14.11 \% \mathrm{SiO}_{2}, 0.24 \% \mathrm{Na}_{2} \mathrm{O}\right.$, $0.422 \%$ alkali, $26.31 \mathrm{MPa}$ CS and $4.75 \mathrm{MPa}$ FS; $28 \mathrm{~d}$ : $14.76 \%$ $\mathrm{SiO}_{2}, 0.29 \% \mathrm{Na}_{2} \mathrm{O}, 0.425 \%$ alkali, $33.4 \mathrm{MPa} \mathrm{CS}$ and $5.2 \mathrm{MPa}$ FS; 90 d: $12.84 \% \mathrm{SiO}_{2}, 0.10 \% \mathrm{Na}_{2} \mathrm{O}, 0.13 \%$ alkali, $31.8 \mathrm{MPa}$ $\mathrm{CS}$, and 5.17 MPa FS). And effect of BP-BCPCCC on CS and FS gaining deals with continuously increasing $\mathrm{SiO}_{2}$. Similar upward movement of $\mathrm{SiO}_{2}$ at BP-BCP is monitored CS and FS gain at BP-BM. Both compositions and strengths develop progressively as seen in the following parentheses ( $7 \mathrm{~d}: 19.59 \%$ $\mathrm{SiO}_{2}, 33.45 \mathrm{MPa}$ CS and $5.16 \mathrm{MPa} F \mathrm{~F} ; 28 \mathrm{~d}: 20.03 \% \mathrm{SiO}_{2}$, 43.53 MPa CS, and 6.76 MPa FS; 90 d: $21.12 \% \mathrm{SiO}_{2}, 45.73 \mathrm{MPa}$ CS and 7.77 MPa FS) (Tables 4, 5, 6, and 7).

\section{Conclusions}

This research was carried out to more effectively explain CS and FS gains associated with BCP-CCC. Chemical compositions of MP-BCP and BP-BCP and CS and FS of MP-BM and $\mathrm{BP}-\mathrm{BM}$ were determined by international standards at 
7th-day, 28th-day, and 90th-day. The results of these experiments support the following conclusions.

(1) At early ages of hardening, CEMI42.5MP6P has a microstructure composed of the gelatinous membrane around the marble powders, layered $\mathrm{CH}$ formations, amorphous C-S-H gel, and ettringite prisms. At the age of 28 days and 90 days, further encapsulation of marble powders into hydration products is observed. However, at the ages of 7 days, CEMI42.5BP20P has a microstructure composed of fibrous C-S-H gel, layered $\mathrm{CH}$ formations, and ettringite prisms. At the age of 28 days and 90 days, further encapsulation of brick powders into hydration products is observed. Compressive strength of the CEMI42.5MP6M samples at whole cure periods is notably lower than that of BP-BCM and RCM samples. This can be explained by the increase of $\mathrm{Ca} / \mathrm{Si}$ ratio from 1.76 up to 2.8 . On the contrary to last conclusion, compressive strength of the CEMI42.5BP20M is the greatest in the mortars. This can be explained by the increase of $\mathrm{Si} / \mathrm{Ca}$ ratios from 0.53 up to 0.96 .

(2) MP-blended cement pastes displayed increasing at $\mathrm{CaO}, \mathrm{MgO}, \mathrm{K}_{2} \mathrm{O}$ and $\mathrm{LOI}$ and reduction at $\mathrm{SiO}_{2}$, $\mathrm{Al}_{2} \mathrm{O}_{3}, \mathrm{Fe}_{2} \mathrm{O}_{3}, \mathrm{MgO}, \mathrm{SO}_{3}, \mathrm{~K}_{2} \mathrm{O}$ and $\mathrm{Na}_{2} \mathrm{O}$ at $7 \mathrm{~d}$; ascent at $\mathrm{MgO}, \mathrm{SO}_{3}$ and $\mathrm{LOI}$ and reduction at $\mathrm{CaO}$, $\mathrm{SiO}_{2}, \mathrm{Al}_{2} \mathrm{O}_{3}, \mathrm{Fe}_{2} \mathrm{O}_{3}, \mathrm{~K}_{2} \mathrm{O}$ and $\mathrm{Na}_{2} \mathrm{O}$ at $28 \mathrm{~d}$; and increasing at $\mathrm{CaO}, \mathrm{Na}_{2} \mathrm{O}$, LOI and alkali and reduction at $\mathrm{SiO}_{2}, \mathrm{Al}_{2} \mathrm{O}_{3}, \mathrm{Fe}_{2} \mathrm{O}_{3}, \mathrm{MgO}, \mathrm{SO}_{3}, \mathrm{~K}_{2} \mathrm{O}$ at $90 \mathrm{~d}$. Regardless of the increasing presence of CS and FS at CEMI42.5BP20M, MP blending up to $6 \%$ showed the highest mortar CS and FS in the presence of MP$\mathrm{BCPCCC}$ at $7 \mathrm{~d}$. This result infers that small blending of MP for cement had positive effect on strength gains of mortars at early ages. At high blending levels up to $35 \%$ with this method being applied in this research, none of MP percent had a greatly positive effect on strength gain at early and later ages. Increasing of LOI and alkali at MP-BCP caused reduction of strength gain at $\mathrm{MP}-\mathrm{BM}$ according to the literature. However, effect of MP-BCPCCC on strength gain of MP-BM deals with fluctuation of $\mathrm{SiO}_{2}, \mathrm{Na}_{2} \mathrm{O}$, and alkali as well as increasing of LOI. Strength gain of MP-BM fluctuates because of vicissitudes of $\mathrm{SiO}_{2}, \mathrm{Na}_{2} \mathrm{O}$, and alkali content at MP-BCP. This result showed that MP blending more than $6 \%$ had no positive effect on strength gains of mortars at early ages.

(3) On the contrary to effects of MP-BCPCCC on strength gain, BP-blended cement pastes displayed reduction at $\mathrm{CaO}, \mathrm{MgO}, \mathrm{Na}_{2} \mathrm{O}$, LOI and alkali, and ascent at $\mathrm{SiO}_{2}, \mathrm{Al}_{2} \mathrm{O}_{3}, \mathrm{Fe}_{2} \mathrm{O}_{3}, \mathrm{SO}_{3}$, and $\mathrm{K}_{2} \mathrm{O}$ at $7 \mathrm{~d}$; decreasing at $\mathrm{CaO}, \mathrm{MgO}$ and $\mathrm{LOI}$ and ascent at $\mathrm{SiO}_{2}$, $\mathrm{Al}_{2} \mathrm{O}_{3}, \mathrm{Fe}_{2} \mathrm{O}_{3}, \mathrm{SO}_{3}$, and $\mathrm{K}_{2} \mathrm{O}, \mathrm{Na}_{2} \mathrm{O}$ and alkali at $28 \mathrm{~d}$; and reducing at $\mathrm{CaO}, \mathrm{MgO}, \mathrm{SO}_{3}$ and LOI of and increasing at $\mathrm{SiO}_{2}, \mathrm{Al}_{2} \mathrm{O}_{3}, \mathrm{Fe}_{2} \mathrm{O}_{3}, \mathrm{~K}_{2} \mathrm{O}, \mathrm{Na}_{2} \mathrm{O}$ and alkali at $90 \mathrm{~d}$. Blending of $\mathrm{BP}$ accelerated tendency of strength gain at later ages because $\mathrm{BP}$ reduced LOI in the BP-BCPCC. CEMI42.5BP20M displayed the greatest CS and FS in the mortars at whole ages. Effects of BP-BCPCCCs on CS and FS gains deals with increasing of $\mathrm{SiO}_{2}$ in BP-BCP. Average of $\mathrm{SiO}_{2}$ tended to increase in BP-BCP continuously. Strength gain at BP-BM acted similar to $\mathrm{SiO}_{2}$ in BP-BCP. Since CEMI42.5BP20M achieved nearly 52.5 MPa compressive strength at $90 \mathrm{~d}, \mathrm{BP}$ blending up to $35 \%$ had a positive effect on strength gains of cement mortars at later ages.

\section{Conflict of Interests}

The author declares that there is no conflict of interests regarding the publication of this paper.

\section{References}

[1] M. S. Kirgiz, The usage of the wastes of marble and brick industries in cement manufacturing as mineralogical additive [Ph.D. thesis], Gazi University Graduate School of Natural and Applied Sciences, Ankara, Turkey, 2007.

[2] V. Corinaldesi, G. Moriconi, and T. R. Naik, "Characterization of marble powder for its use in mortar and concrete," Construction and Building Materials, vol. 24, no. 1, pp. 113-117, 2010.

[3] A. Ergün, "Effects of the usage of diatomite and waste marble powder as partial replacement of cement on the mechanical properties of concrete," Construction and Building Materials, vol. 25, no. 2, pp. 806-812, 2011.

[4] M. Frías, E. Villar, and H. Savastano, "Brazilian sugar cane bagasse ashes from the cogeneration industry as active pozzolans for cement manufacture," Cement and Concrete Composites, vol. 33, no. 4, pp. 490-496, 2011.

[5] C.-T. Galbenis and S. Tsimas, "Use of construction and demolition wastes as raw materials in cement clinker production," China Particulogy, vol. 4, no. 2, pp. 83-85, 2006.

[6] Z. Ge, Z. Gao, R. Sun, and L. Zheng, "Mix design of concrete with recycled clay-brick-powder using the orthogonal design method," Construction and Building Materials, vol. 31, pp. 289293, 2012.

[7] H. Hebhoub, H. Aoun, M. Belachia, H. Houari, and E. Ghorbel, "Use of waste marble aggregates in concrete," Construction and Building Materials, vol. 25, no. 3, pp. 1167-1171, 2011.

[8] G. Kakali, S. Tsivilis, K. Kolovos et al., "Use of secondary mineralizing raw materials in cement production. A case study of a wolframite-stibnite ore," Cement and Concrete Composites, vol. 27, no. 2, pp. 155-161, 2005.

[9] G. Kakali, S. Tsivilis, K. Kolovos et al., "Use of secondary mineralizing raw materials in cement production. The case study of a stibnite ore," Materials Letters, vol. 57, no. 20, pp. 31173123, 2003.

[10] P.C. Kapur and P. D. Vaidyanathan, "Production and properties of alinite cements from steel plant wastes," Cement and Concrete Research, vol. 20, no. 1, pp. 15-24, 1990.

[11] A. Monshi and M. K. Asgarani, "Producing portland cement from iron and steel slags and limestone," Cement and Concrete Research, vol. 29, no. 9, pp. 1373-1377, 1999.

[12] E. Dourdounis, V. Stivanakis, G. N. Angelopoulos et al., "Highalumina cement production from FeNi-ERF slag, limestone and diasporic bauxite," Cement and Concrete Research, vol. 34, no. 6, pp. 941-947, 2004. 
[13] K. Raina and L. K. Janakiraman, "Use of mineralizer in black meal process for improved clinkerization and conservation of energy," Cement and Concrete Research, vol. 28, no. 8, pp. 10931099, 1998.

[14] H. Li, D. K. Agrawal, J. Cheng, and M. R. Silsbee, "Microwave sintering of sulphoaluminate cement with utility wastes," Cement and Concrete Research, vol. 31, no. 9, pp. 1257-1261, 2001.

[15] J. Sun and L. Fang, "Numerical simulation of concrete hollow bricks by the finite volume method," International Journal of Heat and Mass Transfer, vol. 52, no. 23-24, pp. 5598-5607, 2009.

[16] S. Wild, A. Gailius, H. Hansen, L. Pederson, and J. Szwabowski, "Pozzolanic properties of a variety of European clay bricks: comparative study of pozzolanic, chemical and physical properties of clay bricks in four European countries for utilization of pulverized waste clay brick in production of mortar and concrete," Building Research and Information, vol. 25, no. 3, pp. 170-175, 1997.

[17] C. Zhi Yuan and W. Jian Guo, "Bond between marble and cement paste," Cement and Concrete Research, vol. 17, no. 4, pp. 544-552, 1987.

[18] "Standard specification for coal fly ash and raw or calcined natural pozzolan for use in concrete," ASTM C618-12a, ASTM International, West Conshohocken, Pa, USA, 2000.

[19] "Concrete-part 1: Specification, performance, production and conformity," BS EN 206-1:2000, British Standards Institute, London, UK, 2001.

[20] I. Odler, Lea's Chemistry of Cement and Concrete, P.C. Hewlett, London, UK, 1998.

[21] S. Kelham and G. K. Moir, "The effect of cement $\mathrm{C}_{3} \mathrm{~S}$ level on concrete properties," in Proceedings of the 9th International Congress on the Chemistry of Cement, vol. 5, pp. 3-8, NCCBM, Delhi, India, 1992.

[22] B. Obaesk and E. S. Jons, "The influence of the content and distribution of alkalis on the hydration properties of Portland cement," in Proceedings of the 8th International Congress on the Chemistry of Cement, pp. 135-140, Paris, France, 1980.

[23] K. Sobolev, P. Türker, S. Soboleva, and G. Iscioglu, "Utilization of waste glass in ECO-cement: strength properties and microstructural observations," Waste Management, vol. 27, no. 7, pp. 971-976, 2007.

[24] H. F. W. Taylor, "A method for predicting alkali concentration in cement pore solutions," Advances in Cement Research, vol. 1, no. 1, pp. 5-16, 1987.

[25] "Specification for limestone fines for use with Portland cement," BS 7979:2001, British Standards Institute, London, UK, 2012.

[26] "Methods of testing cement-part 2: Chemical analysis of cement," TS EN 196-2, Turkish Standards Institute, Ankara, Turkey, 2012.

[27] "Cement-part 1: Compositions and conformity criteria for common cements," TS EN 197-1, Turkish Standards Institute, Ankara, Turkey, 2012.

[28] "Methods of testing cement-part 1: determination of strength," TS EN 196-1, Turkish Standard Institute, Ankara, Turkey, 2009.

[29] M. A. Abd-El.aziz, S. AbdelAleem, and M. Heikal, "Physicochemical and mechanical characteristics of pozzolanic cement pastes and mortars hydrated at different curing temperatures," Construction and Building Materials, vol. 26, no. 1, pp. 310-316, 2012.

[30] N. Chusilp, C. Jaturapitakkul, and K. Kiattikomol, "Effects of LOI of ground bagasse ash on the compressive strength and sulfate resistance of mortars," Construction and Building Materials, vol. 23, no. 12, pp. 3523-3531, 2009.
[31] S. Guettala and B. Mezghiche, "Compressive strength and hydration with age of cement pastes containing dune sand powder," Construction and Building Materials, vol. 25, no. 3, pp. 1263-1269, 2011.

[32] I. Odler, "Strength of cement (final report)," Materials and Structures, vol. 24, no. 2, pp. 143-157, 1991.

[33] L. Mo and D. K. Panesar, "Effects of accelerated carbonation on the microstructure of Portland cement pastes containing reactive MgO," Cement and Concrete Research, vol. 42, no. 6, pp. 769-777, 2012 

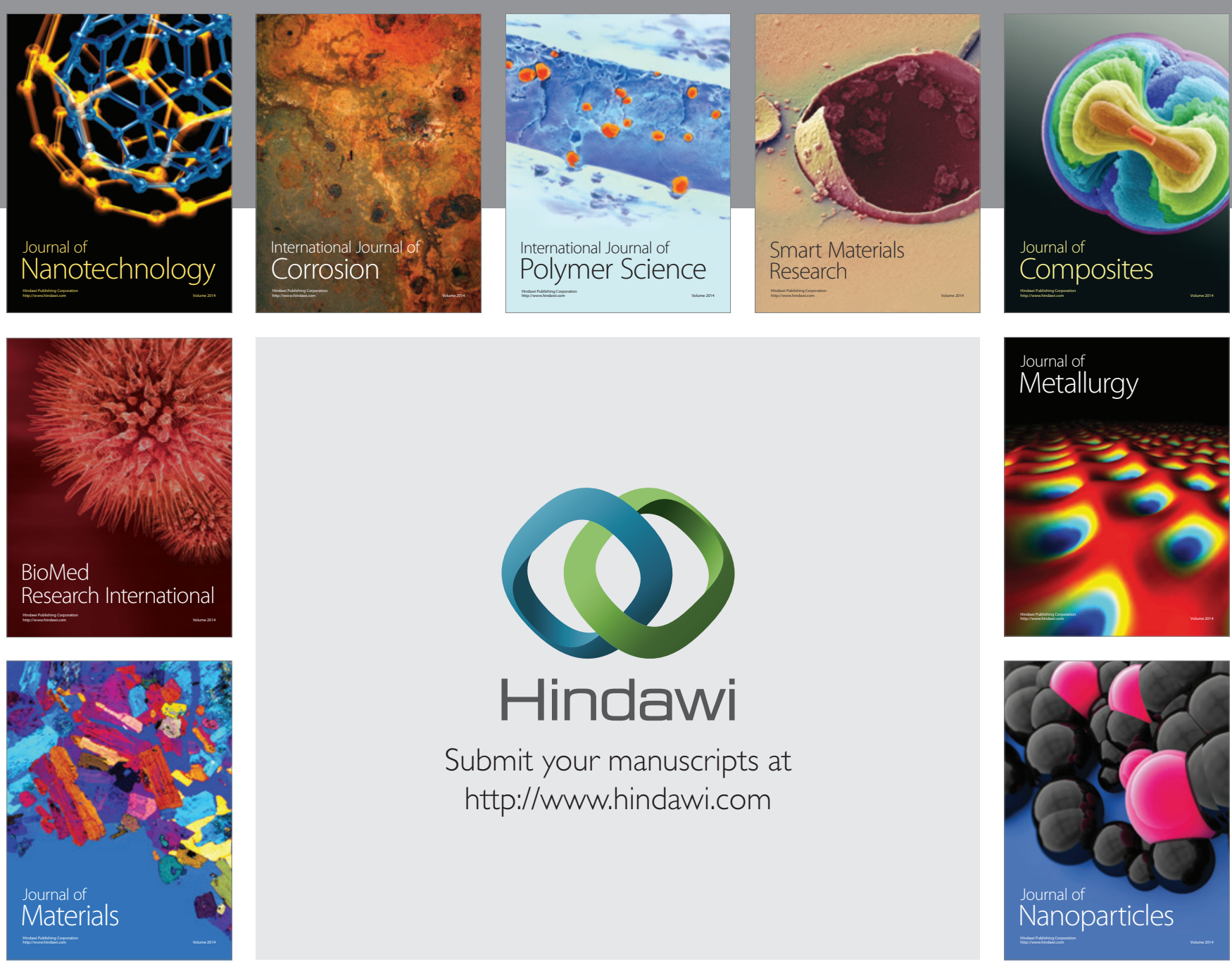

Submit your manuscripts at http://www.hindawi.com
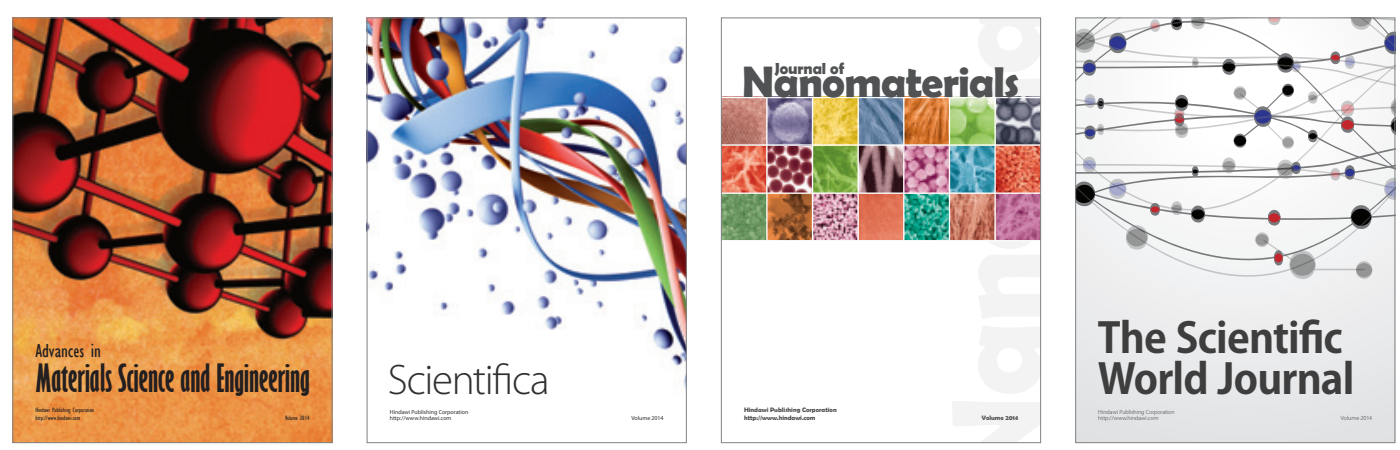

\section{The Scientific World Journal}
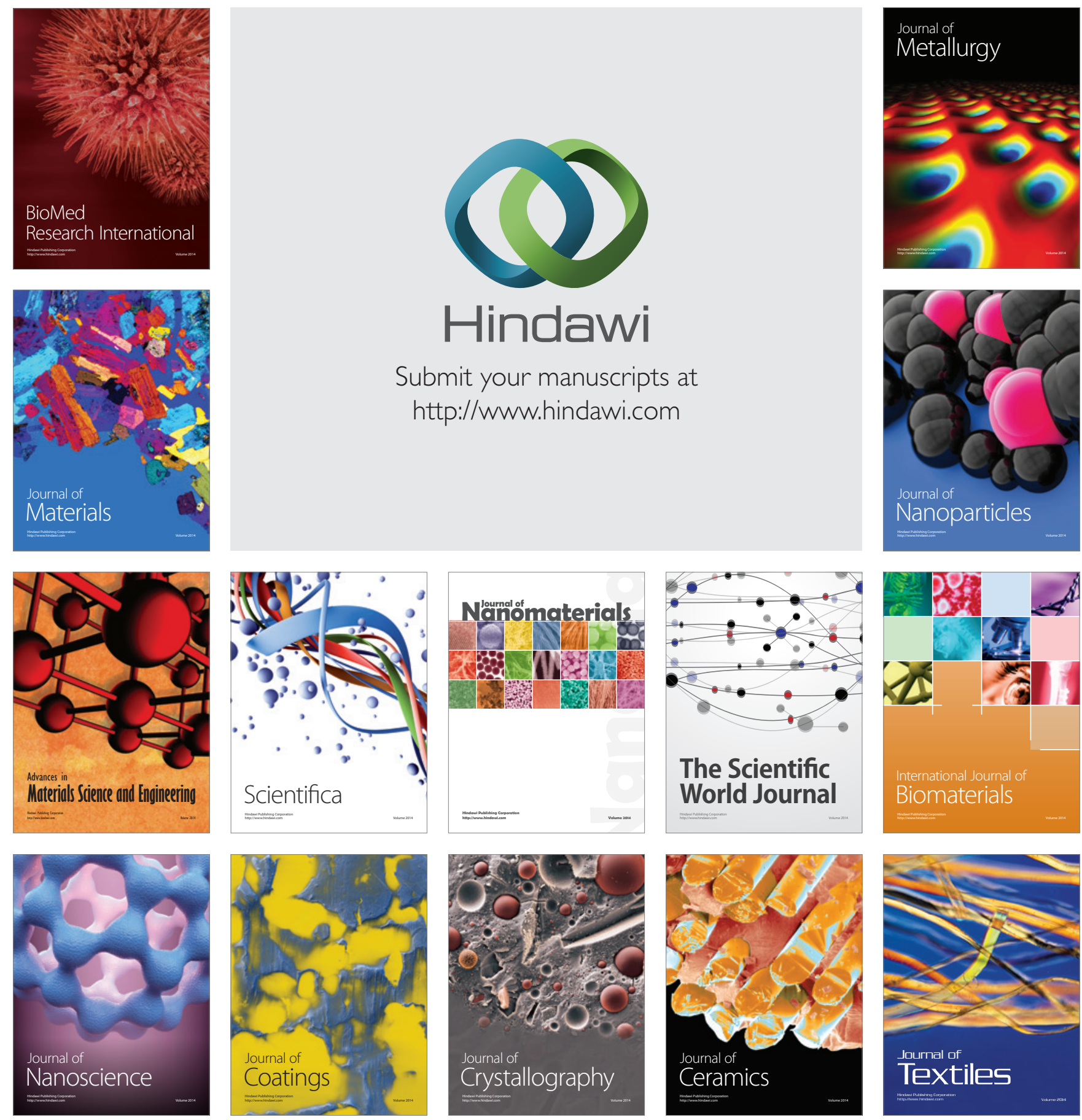